\title{
TAXATION IN THE REPUBLIC OF ARMENIA: AN OVERVIEW AND DISCUSSION FROM THE PERSPECTIVES OF LAW, ECONOMICS AND ETHICS
}

\author{
Robert W. McGee*
}

I. GENERAL PROVISIONS ....................... 97

II. RIGHTS AND RESPONSIBILITIES OF TAXPAYERS; CONTROL OVER

TAX PAYMENTS .......................... 101

III. RESPONSIBILITY FOR THE VIOLATION OF TAX LEGISLATION . . . . 103

IV. GETTING A REFUnd $\ldots \ldots \ldots \ldots \ldots \ldots \ldots \ldots \ldots \ldots \ldots \ldots$

V. OTHER PROVISIONS $\ldots \ldots \ldots \ldots \ldots \ldots \ldots \ldots \ldots \ldots \ldots \ldots$

VI. Concluding COMMENTs $\ldots \ldots \ldots \ldots \ldots \ldots \ldots \ldots \ldots \ldots$

Like many economies in transition, the Republic of Armenia is in the process of adopting market-oriented policies and laws. The current tax law ${ }^{1}$ in Armenia was passed by the National Assembly on April 14, 1997 and was signed by the President on May 12, 1997. The transition rules were quite simple. Upon taking effect, the prior law, which was passed on April 19, 1992, became void. $^{2}$

\section{General Provisions}

The tax procedures in Armenia come from three different sources: 1) tax legislation and other laws on different types of taxes, ${ }^{3}$ ) government decrees, ${ }^{4}$ and 3) legislative norms that are adopted by the Tax Inspectorate or other State administrative bodies. 5 Thus, there are some similarities and differences between the sources of tax rules in Armenia versus those in the United States and other western democracies.

In the United States, the legislative branch passes tax legislation. The same is true in Armenia. However, in Armenia there are also government decrees, which are not a source of tax law in the United States. The advantage of having

* Professor, W. Paul Stillman School of Business, Seton Hall University.

1. See Generally Tax Code, 1997 (Arm.) (All references are to the English language version of the Republic of the Armenia tax law, passed in the National Assembly on April 14, 1997).

2. Tax Code, 1997, art. 39 (Arm.).

3. Id. at art. 2, sec. a.

4. Id. at sec. b.

5. Id. at sec. c. 
government decrees as part of the legal process is that it allows for faster changes in the law. If something needs to be fixed, it can be fixed quickly, without the need to first gather the necessary number of votes from the legislature. The problem with allowing government decrees to have the force of law is that there is no legislative input. If those who have the authority to issue such decrees are incompetent or evil, a great deal of damage may be done. Such decrees can be used to reward friends or punish enemies. One of the strengths of the legal system in the United States is the separation of powers. The legislative branch passes the laws and the executive branch enforces them. This separation of powers doctrine ${ }^{6}$ acts as a safeguard against government abuse. The Armenian tax system, or legal system in general, does not have this safeguard built into the system to the same extent, although there are three separate branches of government.

The third source of tax regulations, legislative norms, might be compared to Internal Revenue Code Regulations that are written by the United States Treasury Department and to Revenue Rulings and Revenue Procedures, which are written by the Internal Revenue Service in the United States. In Armenia, these legislative norms have the force of law. In the United States, Internal Revenue Code Regulations have the force of law, although occasionally a regulation is declared to be invalid for one reason or another. Internal Revenue Service publications like Revenue Rulings and Revenue Procedures do not have the force of law, but taxpayers who ignore them do so at their peril.

The problem with this source of law is that it is generated by the very people who are in charge of collecting the tax. Thus, there may be a tendency to interpret the law, or to make new law, that benefits the tax collector at the expense of the taxpaying public. One of the main strengths of the Separation of Powers Doctrine is that it provides a legal structure to prevent this potential abuse of power.

The Separation of Powers Doctrine has been substantially eroded in the United States, especially since the 1930s, when a number of administrative agencies were created in the executive branch. These agencies have grown in size and power to such an extent that the judges who would hear cases on the violation of the Separation of Powers Doctrine are afraid to declare some administrative agency unconstitutional for fear that their ruling would be used

6. The Separation of Powers Doctrine had its origins in the political writings of the seventeenth and eighteenth centuries. The United States was the first country to adopt it as part of its constitutional structure. The Separation of Powers Doctrine is constructed around the belief that a government that has its power divided among the executive, legislative and judicial branches has less ability to abuse power than a government that has these powers centralized in a single branch. The legislative branch makes the laws, the executive branch enforces the laws, and the judicial branch interprets the laws. A system of checks and balances is thus established to minimize the amount of abuse that might otherwise take place. 
as precedent to eventually hold that all such administrative agencies that exercise legislative and judicial power are unconstitutional. ${ }^{\text {? }}$

The Armenian tax law states that taxes are compulsory payments, collected for state and public welfare. They are to be collected from legal and physical persons and from enterprises. ${ }^{8}$ Those who are philosophically inclined might question the meaning of state welfare and public welfare, and whether they might be appropriate or true recipients of tax revenues.

The philosophical problem with collecting tax revenues for state welfare is that the state is supposed to represent the people, but state welfare, if such a thing exists, runs contrary to the interests of the taxpaying public. It is in the state's interest to expand its power and scope, whereas it is in the interest of individuals to keep the state small enough that it is not able to do much damage to the individuals within its borders or without. There is a built-in and irreconcilable conflict between state interests and individuals interests. At least that is true once the state grows beyond the minimal state. ${ }^{9}$

Collecting taxes for the public welfare is a benign enough goal. The problem is that many states collect taxes for reasons that actually harm public welfare rather than enhance it. An ideal tax, if there is one, has the sole aim of collecting revenue. The problem is that many taxes are created to further social engineering goals rather than revenue collection goals. The graduated income tax, for example, exists mostly to reduce income inequality, which is social engineering at its worst. Karl Marx advocated a graduated income tax in his Communist Manifesto as a means of destroying the free enterprise system, which he disparagingly referred to as capitalism.

Economists have made a number of utilitarian arguments against the graduated income tax. ${ }^{10}$ It destroys incentives of the most productive people. It retards economic growth by reducing the amount of capital available for investment and job creation. ${ }^{11}$

7. In the United States, a number of administrative agencies exercise both legislative and judicial power although they are in the executive branch. For example, the Internal Revenue Service, which is a subdivision of the Treasury Department, which is in the executive branch, issues pronouncements such as Revenue Rulings and Revenue Procedures, which have the force of law for all practical purposes, since a taxpayer who ignores them does so at his peril. The Treasury Department writes the regulations that expand, clarify, and sometimes alter the tax laws that the legislative branch has passed. The Internal Revenue Service also has its own court, the Tax Court, which hears and decides thousands of tax cases. It is an administrative court that is in the executive branch.

8. Tax Code, 1997, art. 3 (Arm.).

9. For more on the concept of a minimal state from the philosophical perspective, see generally ROBERT NOZICK, ANARCHY, STATE AND UTOPIA, BASIC BOOK, INC. (1974).

10. Walter J. Blum \& Harry Kalven, JR., The Uneasy Case for Progressive Taxation (1953); F.A. HAYEK, THE CASE AGAINST PROGRESSIVE INCOME TAXES, FREEMAN 229-232 (1953).

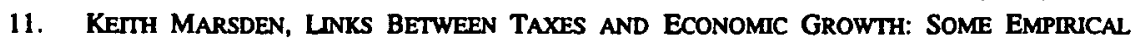
EVIDENCE (World Bank Staff Working Paper No. 605, 1983). 
There is also the fairness argument. There are basically only two views of government. Either the government is the servant and the people are the masters, or the government is the master and the people are the servants. The graduated income tax is based on the view that the government is the master. As Karl Marx said, "From each according to his abilities; to each according to his needs."12 If government were viewed as the servant, the view might be, "From each according to the benefits received."

Unfortunately, the tax laws of Armenia tend to be of the Marxist variety. ${ }^{13}$ The enterprise profit tax, for example, varies between $15 \%$ and $25 \%$, which, although lower than the rates in most countries, is, nevertheless, graduated. ${ }^{14}$ The profit tax on gambling games and lotteries, although not graduated, is set at a confiscatory $70 \% .^{15}$ Individual income taxes are assessed at three rates, $15 \%, 25 \%$ and $30 \% .^{16}$

The Armenian tax system engages in other forms of social engineering in addition to attempting to reduce income inequality. The excise tax law for example punishes those who sell or consume caviar, alcohol and tobacco products while rewarding those who make coats from sheep fur for employees and the army. ${ }^{17}$

The value-added tax (VAT) is assessed at a single rate, ${ }^{18}$ although there are exemptions for certain socially desirable activities and products. ${ }^{19}$ Exports are subsidized by a zero tax rate. ${ }^{20}$

One concept imbedded in the Armenian tax code that might be adopted by the United States is the provision relating to when tax law changes should be made. The Armenian tax law states that changes in tax rates, the introduction or termination of a tax may generally take place only at the beginning of a fiscal year. ${ }^{21}$ That would eliminate the need to allocate by days or to deal with the complexities that result when the rules are changed during the year, as is so often done in the United States.

12. GEORgE SEIDES, THE GREAT ThOughts 274 (1985). The original wording was "Jeder nach seinen Fahigkeiten, jedem nach seinen Bedirfnissen." Id. Louis Blanc, the French socialist, said basically the same thing in 1848.

13. As are those of the United States and every other country that has graduated tax rates.

14. Tax Code, 1997, art. 33, sec. 1 (Arm.) (Law on Enterprise Profit Tax).

15. Id. at sec. 2 (Law on Enterprise Profit Tax).

16. Id. at art. 18 (Personal income Tax).

17. Id. at art. 5 (Excise Tax), (signed into law by the President on June 24, 1997). The tax rate on caviar is $200 \%$. Id. On tobacco products it is $100 \%$. Id. On alcohol, the rate varies between $50 \%$ and $125 \%$. Id. The rate on coats made of sheep fur for employees or the army is zero percent. Id.

18. Id. at art. 9 (Law on Value Added Tax) (signed into law by the President on June 16, 1997).

19. Tax Code, 1997, art. 15 (Arm.).

20. Id. at art. 16.

21. Id. at art. 8. 
The Armenian tax credit is quite simple. Taxes paid by taxpayers in Armenia shall be reduced by the amount of tax collected from the taxpayer outside Armenia. ${ }^{22}$ This rule is much less complicated than the United States rule. It avoids the possibility of double-taxation.

Armenia assesses six kinds of taxes, ${ }^{23}$ the enterprise profit tax, ${ }^{24}$ the personal income tax, ${ }^{25}$ the excise tax, ${ }^{26}$ the Value Added $\mathrm{Tax},{ }^{27}$ the property $\operatorname{tax}^{28}$ and the land tax.

\section{RIGHTS AND RESPONSIBILITIES OF TAXPAYERS; CONTROL OVER TAX PAYMENTS}

A taxpayer has the following rights:

a. be introduced to the results of checking his activity, ${ }^{29}$

b. submit to Tax Inspection explanatory notes on tax accounting, and payment, ${ }^{30}$

c. appeal against activities of Tax Inspectorate, as in accordance with the legislation, ${ }^{31}$

d. apply for obtaining tax privileges, as defined by the legislation. ${ }^{32}$

A taxpayer has the following responsibilities:

a. to account income, and to submit statement of accounts, ${ }^{33}$

b. to account amounts of taxes to be paid, and pay them, unless envisaged otherwise by the legislation, ${ }^{34}$

c. to submit to Tax Inspection tax reports, and other documents, as envisaged by the legislation, ${ }^{35}$

22. Id. at art. 11.

23. Id. at art. 12.

24. See generally Law on Enterprise Profit Tax, 1997 (Arm.) (enacted by the National Assembly on Sept. 30, 1997 and signed by the President on Nov. 27, 1997).

25. See generally Law on Personal Income Tax, 1997 (Arm) (adopted by the National Assembly on Dec. 27, 1997 and signed by the President on Dec. 30, 1997).

26. See generally Law on Excise Tax, 1997 (Arm.) (signed by the President on June 24, 1997).

27. See generally Law on Value Added Tax, 1997 (Arm.) (enacted by the National Assembly on May 14, 1997 and signed by the President on June 16, 1997).

28. Tax Code, 1997 (Arm.).

29. Id. at art. 14, sec. a.

30. Id. at sec. b.

31. Id. at sec. c.

32. Id. at sec. d.

33. Tax Code, 1997, art. 15, sec. a (Arm.).

34. Id. at sec. b.

35. Id. at sec. $\mathrm{c}$. 
d. to pay in due time taxes, and tax advances, if envisaged by the legislation, ${ }^{36}$

e. provide necessary conditions for checks, conducted by the Tax Inspectorate, ${ }^{37}$

f. submit documents, verifying his fights for tax privileges, ${ }^{38}$

g. to make corrections in the accounts, if errors are found during the checks conducted by Tax Inspectorate. ${ }^{39}$

Taxpayers have a month to register for a taxpayer identification number after receiving a taxpayer's license. ${ }^{40}$ Tax liability is terminated upon death, ${ }^{41}$ which is different from the treatment in the United States, where the deceased taxpayer's estate assumes responsibility for paying the tax. If a legal person or enterprise is restructured, the outstanding tax liabilities are assumed by the successor. ${ }^{42}$

The restructuring provision is an interesting one because it does not go into any further detail about what constitutes a restructuring. If the restructuring is by transfer of shares, it is easy to identify the old and new owners. But what if the restructuring is by the sale of assets, where the old and new owners are not quite identical? Who is liable for tax in such a case? The law is unclear.

If outstanding tax liabilities have been discovered after the liquidation of a legal person, the court may assign them to the major owners or members of management if these liabilities arose within one year of liquidation as a result of mistakes made by these persons. ${ }^{43}$ Thus, there is a one-year statute of limitations in which to pierce the corporate veil.

Which major owners or managers would be liable is not stated. Would a bookkeeper be liable, or would the bookkeeper's boss be liable? Would the president of the enterprise be liable if it was the bookkeeper who made the mistake without the president's knowledge? If the president told the bookkeeper to calculate the amount of tax liability incorrectly, would the bookkeeper be liable? Would it be joint and several liability with the right of contribution?

Questions might also arise about what constitutes a mistake. Is an underestimate of tax liability a mistake, or is it merely an underestimate? What

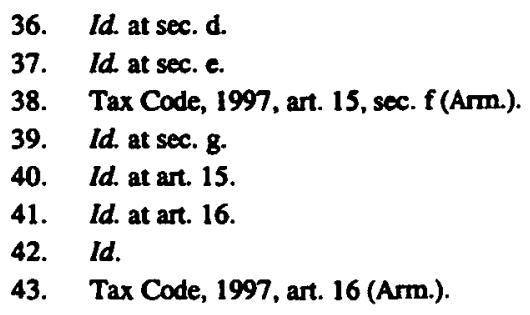


if a mistake is discovered that, upon correction, would result in a tax refund? Who is entitled to receive the refund?

A number of questions arise because the tax law does not cover these points. Carefully worded language in the corporate charter might spell out who is entitled to a tax refund in the event of liquidation, but it is unlikely that those who draft corporate charters would think to include such a provision.

Information obtained illegally during the course of a tax inspection may not be used to collect taxes. ${ }^{44}$ Thus, the tax inspector is not able to benefit by breaking the law, which reduces the incentive for doing so.

Information may not serve as the basis for accounting and collecting taxes unless the taxpayer has become familiar with it. ${ }^{45}$ This provision provides a measure of basic fairness and allows the taxpayer to introduce information to challenge the veracity of the information that is otherwise used to assess and collect taxes.

Legal persons, enterprises without the status of a legal person, entrepreneurs, and state and local government bodies shall provide the Tax Inspectorate with information on the activities associated with the taxpayers, and the income paid to physical persons and taxes collected from the income, in accordance with procedures defined by legislation. ${ }^{46}$

\section{RESPONSIBILITY FOR THE VIOLATION OF TAX LEGISLATION}

Taxpayers, and their management in the case of enterprises, institutions and other organizations, are responsible for the correct tax accounting and timely payment unless otherwise envisaged by legislation. ${ }^{47}$ Taxpayers who do not submit the accounting documents, or who submit documents that do not comply with the requirements, shall have the Tax Inspectorate perform its own accounting, based on the following: ${ }^{48}$
a. Taxpayer's assets taxed turnover
b. Expenses on the production and turnover
c. Inventory results
d. Information obtained from third persons
e. Prices and costs used by other persons in similar cases
f. Other norms set by the government
44. Id. at art. 18.
45. Id. at art. 19.
46. Id. at art. 20.
47. Id. at art. 22.
48. Tax Code, 1997, art. 22 (Arm.). 
There are penalties for delay in payment. If there is a 90 day delay in paying, a fine equal to $0.1 \%$ of the total amount is assessed. ${ }^{49}$ If payment is delayed by more than 90 days, the fine is $0.3 \%$ of the total amount of tax due. ${ }^{50}$ For taxpayers who understand the time value of money, this provision encourages them to delay payment and invest the proceeds in some kind of income generating account.

A fine is imposed if an accounting statement is submitted more than two months late. ${ }^{51}$ The fine is equal to $5 \%$ of the total amount due for each 15 days of delay, not to exceed the total amount due. ${ }^{52}$

A fine equal to $10 \%$ of the outstanding tax liability is assessed if the taxpayer either did not carry out an accounting or if the accounting was done improperly. ${ }^{53}$ This penalty might be exceedingly harsh in some cases. For example, take the case of a taxpayer who completed $99 \%$ of the accounting properly but made a mistake on some minor item. According to the wording of this penalty provision, the taxpayer is assessed a $10 \%$ fine on the entire amount of the tax liability, when in fact the mistake that was made might have been quite minor. What if the mistake was in the government's favor? Apparently, the taxpayer would still be assessed a $10 \%$ penalty, which seems grossly unfair. $^{54}$

If an item is not included on a tax declaration, or is partially concealed, meaning not properly accounted for, the taxpayer is liable for the full amount of tax plus a $50 \%$ penalty. If the taxed object is missing or partially concealed a second time, the penalty rises to $100 \% .^{55}$ There is nothing in this tax law that mentions prison as a possible penalty for concealment of tax liability. ${ }^{56}$

49. Id. at art. 23

50. Id.

51. Id. at art. 24 .

52. Id.

53. Tax Code, 1997, art. 25 (Arm.).

54. Joan Caplin, 6 Mistakes Even the Tax Pros Make, MONEY, Mar. 1998, at 104-106. If a similar penalty provision were enacted into the United States tax code, it is likely that every taxpayer that is audited would have to pay the penalty. In November 1997, for the eighth time since 1987, MONEY magazine conducted a survey of practitioners to see how accurately they were able to prepare tax returns. In the survey that was published in the March, 1998 issue, all 46 tax preparers who completed the survey made at least one mistake. For the seventh time in the history of the MONEY magazine survey, no two tax preparers came up with the same tax liability. Participants in the survey consisted of 31 certified public accountants, 12 enrolled agents and three other individuals who prepare tax returns for a living.

55. Tax Code, 1997, art. 27 (Arm.).

56. THE EThics Of TAX EVASION 306-314 (Robert W. McGee, ed. 1998); It might be mentioned that tax evasion is widespread in Eastern Europe and the CIS countries. The main reasons for the widespread evasion are the belief that the government is corrupt and therefore not entitled to any tax revenue, and the absence of an infrastructure that lends itself to the easy reporting of taxable income or its collection. For a discussion of tax evasion in Russia; see VLADIMIR V. VAGUINE, THE "SHADOW ECONOMY" AND TAX EVASION IN RUSSIA, for a discussion of tax evasion in Bulgaria, see GuEORGUI SMATRAKALEV, WALKING 
However, that does not means that tax evaders cannot go to prison because there is another section in the law that states that other types of penalties and fines might be imposed if other provisions of the tax laws are violated. ${ }^{57}$

If the product of entrepreneurial activity, including goods and services to be delivered or sold, is not registered in accordance with procedures set forth by the government, the fine shall be equal to the total cost of production. ${ }^{58}$ If the goods or services are sold at a price that exceeds the registered price, the fine is equal to the difference between the registered price and the actual price. ${ }^{59}$ However, neither of these fines shall be collected if the violation occurs during a period in which the taxpayer provides an accounting declaration. ${ }^{60}$

Such a provision is totally missing from the United States tax code. In the United States there is generally no need to report prices to the government. Setting prices is seen as an activity that is none of the government's business. It is strange that a government that is trying to convert to a market system would retain such a provision.

Taxpayers are to pay the taxes and fines within ten days after receiving notification from the Tax Inspectorate. ${ }^{61}$ Failure to do so may result in seizure of the taxpayer's property. ${ }^{62}$ The Tax Inspectorate may apply to the court for seizure.

This procedure seems harsh and subject to potential abuse. What if the Tax Inspectorate notification states a tax figure that is grossly overstated? What recourse does a taxpayer have other than paying whatever the Tax Inspectorate thinks is due? What if the amount due is a few dollars? Does the Tax Inspectorate have the right to seize all the taxpayer's property?

In the United States, the policy is much different. The Internal Revenue Service first notifies the taxpayer of the alleged deficiency. The taxpayer has 30 days to respond. A series of 30 day and 90 day letters then go back and forth. If various levels of administrative review do not resolve the issue, the taxpayer can petition the Tax Court to hear the case, or can pay the tax and sue for a refund in either the Claims Court or the appropriate federal District Court.

ON THE EDGE: BULGARIA AND THE TRANSTION TO A MARKET ECONOMY, in THE ETHICS OF TAX EVASION 316-329 (Robert W. McGee, ed. 1998); for a discussion of tax evasion in Greece, see APOSTOLOS A. BALLAS \& HARIDImos Tsoukas, Consequences of Distrust: The Vicious Circle of Tax Evasion in Greece, in THE ETHICS OF TAX EVASION 284-304 (Robert W. McGee, ed. 1998); for a sociological and cultural discussion of tax evasion, see AlFONSO MORALES, Income Tax Compliance and Altermative Views of Ethics and Human Nature, in THE ETHICS OF TAX EVASION 242-258 (Robert W. McGee, ed. 1998).

57. Tax Code, 1997, art. 32 (Arm.).

58. Id. at art. 28.

59. Id.

60. Id.

61. Id. at art. 29.

62. Tax Code, 1997, art. 30 (Arm.). 
Although there are possibilities for abuse in the United States tax system, the due process afforded most taxpayers minimized the potential for abuse..$^{63}$ This level of due process is absent from the Armenian tax system.

Evidence of this lack of due process may be seen in the provision that allows the Tax Inspectorate to collect even before taxes are due. There is a provision in the tax law that permits the Tax Inspectorate to collect taxes before the regular due time if there is evidence that a taxpayer with outstanding tax liabilities is destroying the objects of income or concealing income, thus making it impossible to collect taxes. The Tax Inspectorate may require the submission of accounting statements, declarations or other documents before they would ordinarily be due. ${ }^{64}$

Such a rule violates due process and may lead to abuse. There really are no safeguards to prevent the Tax Inspectorate from targeting anyone it wishes, merely to solicit a bribe. From conversations the author has had with numerous Armenians, tax inspectors have a reputation for soliciting bribes. Based on the opinions of the average Armenian, it could be concluded that the average tax inspector would accept a bribe. Some people become tax inspectors for that very reason, since the pay is low and the opportunity for making extra income is great.

\section{GETTING A REFUND}

If a taxpayer is entitled to a tax refund, the amount of the refund will be netted with other tax obligations and refunded to him within 30 days after receiving the application from the taxpayer. ${ }^{65}$ There is a special procedure for refunding excess VAT and excise taxes. ${ }^{66}$

If an employer does not withhold taxes for employees, the amount of tax due may be collected from the employer. ${ }^{67}$ The exact language of the English language translation reads as follows:

If an employer does not collect (keep) taxes from the employee in due time, the amounts shall be collected from the employer after discovery, for a period not exceeding the last three months, and the remaining tax obligations shall be covered by the employer. ${ }^{68}$

63. GeORge HaNSON, TO Harass OUR PeOPLE: THE IRS AND GOVERNMENT ABUSE Of POWER (A Positive Publications Book, 1984). Although the system in the Unites States goes a long way toward eliminating abuse by tax authorities, it has not been able to eliminate abuses. See also, DAVDD BURNHAM, A LAW UNTO ITSEl F: POWER, POLTICS AND THE IRS (Random House, Inc., 1989).

64. Tax Code, 1997, art. 31 (Arm.).

65. Id. at art. 33.

66. Id.

67. Id. at art. 34 .

68. Id. 
If the employer withholds too much from the employee's wages, the excess shall be returned within $\mathbf{3 0}$ days after discovery, for the period of the previous three years. ${ }^{69}$

Taxpayers who incur a loss as the result of the Tax Inspectorate's violations shall be reimbursed in accordance with legal procedure. ${ }^{70}$ This provision is much better than the provision in the United States tax code. In the United States, the IRS can unjustly confiscate a taxpayer's house and sell it for ten cents on the dollar. If it later turns out that the house was wrongly confiscated and sold, the taxpayer is only entitled to the ten cents the IRS collected, not the market value of the house. Worse yet, the taxpayer might have to sue the IRS to get even that. In one case, a taxpayer who was entitled to such a refund had to agree not to sue the IRS as a condition of having the property returned, even after the court said that the taxpayer was entitled to a refund. $^{71}$

\section{OTHER PROVISIONS}

Taxpayers may appeal activities of the Tax Inspectorate officers to the senior body within the Tax Inspectorate within 30 days. ${ }^{72}$ A decision regarding the appeal shall be made within thirty days thereafter. Appeals against these decisions may be appealed to a higher body or to the court within one month after receiving notification. ${ }^{73}$ The taxpayer and/or his representative may be present during the examination of the appeal. ${ }^{74}$ An appeal against the activities of the Tax Inspection officers does not suspend further collection of taxes. However, the tax body that examines the appeal may suspend tax collection until a decision is made. ${ }^{75}$

The provisions of an international agreement take precedence over the provisions of the tax law for those international agreements that were entered into after the current law was passed. ${ }^{76}$ The previous procedures will be effective for international agreements signed before the current tax law took effect. ${ }^{n}$

69. Tax Code, 1997, art. 34 (Arm.).

70. Id. at art. 35 .

71. George hanson, To Harass OUR People: THE IRS AND GOVERnMent ABUSE OF POWER (A Positive Publications Book, 1984). For numerous documented cases of IRS abuse, see also DAVID BURNHAM, A LAW UNTO ITSElf: POWER, POLmICS AND THE IRS (Random House, lnc., 1989).

72. Tax Code, art. 36 (Arm.).

73. Id.

74. Id.

75. Id. at art. 37.

76. Id. at arts. 38, 44.

77. Tax Code, 1997, art. 44 (Arm.). 


\section{CONCLUding COMMENTS}

For one who is familiar with the United States tax code, one is struck by the relative simplicity of the Armenian tax law. The Armenian tax law has little or no complexity compared to the mammoth United States tax law, which has evolved over more than eight decades. ${ }^{78}$ On the other hand, there is not nearly as much guidance, which leaves room for interpretation. But the United States tax code also leaves a lot of room for much interpretation. The Armenian tax system has some provisions that could lead to abuse and there are inadequate safeguards to prevent abuse. The United States tax system has safeguards, but IRS officials have often ignored those safeguards and have abused the law on numerous occasions. Such abuses have led Congress to pass several Taxpayers' Bill of Rights legislation. So even if the Armenian legislature amended the tax law to include safeguards, just having them on the books might not be sufficient to prevent abuses. But it might help.

Armenian tax rates are lower than those in most other countries. Thus, Armenia is at a competitive advantage, all other things being equal. All other things are not equal, of course. After the breakup of the Soviet Union there remains a bit of an anti-capitalistic mentality, which impedes investment and economic growth. This mentality is present in all countries to a certain extent. However, it is more prevalent in former Soviet countries, especially those that became part on the Soviet Union in the early days, as Armenia did. ${ }^{79}$ Fortunately, Armenia does not seem to be infected by this anti-capitalistic virus to the same extent as most other countries of Eastern Europe and the CIS that I have visited. One hesitates to say that Armenians have entrepreneurship in their blood without empirical evidence and scientific studies of genes to back up the statement, but it seems to be true. After the 1915 Diaspora brought on by the Turkish genocide, Armenians fled to the Middle East, Europe, North America and elsewhere. Many of them became quite successful in business.

There is also rampant corruption. As mentioned previously, tax officials, the police and the army are known for taking bribes. Corruption deters some foreign investment but not all foreign investors refuse to invest in countries that are corrupt. Some investors probably prefer such an environment.

Foreign investors hesitate to invest in a company that does not issue financial statements that they can place confidence in. Armenia has gone a long way toward eliminating that competitive disadvantage by the partial adoption of International Accounting Standards. It adopted 15 International Accounting

78. U.S CONST. amend. XVI.

79. LUDWIG VON MISES, THE ANTI-CAPTTALISTIC MENTALTTY (1956); ROBERT SHEAFFER, RESENTMENT AGAINST ACHIEVEMENT: UNDERSTANDING THE ASSUALT UPON ABIITY (1988); HELMUT SCHOECK, ENVY: A THEORY OF SOCIAL BEHAVIOUR (1966). 
Standards toward the end of 1998 and has plans to adopt most or all of the rest of them within the next two years. Some officials in the Tax Inspectorate resent that they were not consulted before the adoption process was in the final stages. The Armenian accounting system is fine just the way it is. Some of the people who were involved in the adoption of International Accounting Standards in Armenia are concerned that tax inspectors will punish Armenian companies once they convert their internal accounting records and procedures to comply with International Accounting Standards. The tax inspectors do not have any training in International Accounting Standards, they do not understand them; and what they do not understand they will not approve. The accountants who work in the private sector also are not familiar with the International Accounting Standards, for the most part. How the accounting community of a whole country can get up to speed on International Accounting Standards in a short period of time will be quite a feat. But they are trying, as are the accountants in a number of CIS republics. 